\title{
PEMAKAIAN SONGKET DALAM PERUBAHAN PERANAN PEREMPUAN MINANGKABAU DI MASYARAKAT
}

\author{
Firman Firman \\ Jurusan Bimbingan dan Konseling FIP UNP \\ Email : firman@konselor.org
}

\section{A. Pendahuluan}

Salah satu ciri menonjol dari suku Minangkabau dibandingkan dengan suku bangsa lainnya, yaitu sistem kekerabatan matrilinial dengan menelusuri ikatan kekerabatan melalui garis ibu. Sistim kekerabatan matrilinial Minangkabau mempunyai ciri-ciri sebagai berikut : (1) keturunan dan pembentukan kumpulan diperhitungkan menurut garis keturuan ibu, (2) perkawinan bersifat matrilokal; (3) anggota kelompok kerabat merasa bersaudara kandung, senasib, sehina, semalu; (4) kekuasaan hakiki pada ibu dan kekuasaan teknis pada mamak dalam kaum dan suku; (5) pola tempat tinggal bercorak dwilokal; (6) kesatuan keluarga terkecil adalah paruik yang bersifat geneologis; serta (7) pusaka tinggi turun dari mamak kepada kemenakan (Malinowsky dalam Rajab, 1969:17; Kato, 1989:54-55; Mardanas, 1991:9-10).

Prinsip dasar dalam sistim kekerabatan matrilinial bertumpu pada ikatan keluarga melalui garis ibu dan kaum perempuanlah penerus keturunan. Garis keturunan dalam suku Minangkabau mempunyai arti dalam pewarisan harta pusaka. Ayah dalam sistim kekerabatan di Minangkabau tidak termasuk anggota keluarga istri dan anak-anaknya, sama halnya dengan seorang anak dari saudara laki-laki termasuk keluarga lain dari ayahnya. Sehubungan dengan hal itu, di dalam masyarakat Minangkabau tradisional keluarga batih menjadi kabur. 
Perempuan dalam sistem matrilineal Minangkabau diposisikan sebagai pengikat, pemelihara, penyimpan harta kekayaan sebagaimana diungkapkan pepatah adat amban puruak atau tempat penyimpanan. Perempuan dalam hal ini diberi hak untuk memiliki harta pusaka, sedangkan laki-laki diberi hak untuk mengatur dan mempertahankannya. Perempuan dipandang sebagai tempat meminta air disaat haus dan meminta makan di saat lapar.

Dewasa ini perubahan sosial melanda kehidupan masyarakat Minangkabau, peran dan posisi perempuan makin bergeser dari sektor domestik ke sektor publik. Sejak kemerdekaan Negara Republik Indonesia perubahan kebijakan politik dan sosial ekonomi mewarnai kehidupan perempuan di Minangkabau. Kekuatan perempuan semakin meningkatkan peran dan posisinya di masyarakat, yang dipicu oleh semakin melemahnya sistem adat itu sendiri. Kelemahan sistem adat terutama menurunnya kekuasaan mamak dan penghulu di sektor ekonomi keluarga, suku dan kaum sehingga menyebabkan meningkatnya posisi perempuan dan sumando (suami saaudara perempuan) dalam pemenuhan ekonomi keluarganya.

Masa penjajahan kolonial, kebiasaan merantau dilakukan oleh laki-laki sebagai aktifitas menunggu panen datang. Melalui merantau terbuka lapangan pekerjaan baru, sehingga harta penghasilan semakin menonjol. Selanjutnya perempuan yang merantau mengikuti suaminya walaupun masih ada beberapa ninik mamak yang menolak anak kemenakannya dibawa ke rantau oleh suami dengan alasan untuk melindungi aset keluarganya di desa. Dewasa ini merantau dan mengikuti pendidikan di luar Minangkabau merupakan suatu hal yang lumrah bagi perempuan Minangkabau. 
Tidak jarang perempuan pergi merantau untuk keperluan mencari pekerjaan, karena terbatasnya lapangan pekerjaan yang tersedia di Minangkabau.

Kontak budaya selama diperantauan antara perempuan Minangkabau dengan etnik lain telah menyebabkan berbagai perubahan dalam berperilaku. Kebiasaan yang tidak praktis dan ekonomi yang mereka bawa dari kampung halaman mulai berubah. Begitu juga pemilihan gaya dan mode pakaian dalam kehidupan sehari-hari maupun untuk ke pesta. Tenunan songket yang menghiasai baju kurang,salendang dan kodek dari kain balapak sudah mulai ditinggalkan, mengigat harga mahal dan kurang praktis. Sebagian baju yang mereka pakai terbuat dari bahan yang fleksibel serta harganya terjangkau. Walaupun demikian tenunan songket bagi perempuan Minangkabau diperantau adalah pakai memiliki edentitas tersendiri dan dipakai pada acara yang sangat terhormat.

Salah satu pakaian yang menggambarkan identitas etnik dan sering dipakai oleh perempuan Minangkabau dalam upacara adat adalah tenunan songket. Kain tenun songket tradisional di Minangkabau mempunyai makna dan motif tersendiri bila dibandingkan dengan tenunan songket lainnya. Tenun songket bagi perempuan Minangkabau tidak dapat dipisahkan dengan upacara adat. Setiap upacara adat di laksanakan, setiap perempuan sudah dipastikan memakai pakaian tenun songket. Dewasa ini tenunan songket bagi perempuan Minangkabau tidak hanya digunakan untuk upacara adat saja, tetapi sudah kegiatan lain, seperti menghadiri acara wisuda, hiasan interior dan sovenir lainnya.

Berdasarkan uraian tersebut, tulisan ini bermaksud untuk memaparkan pemakaian tenunan songket secara tradisional oleh Bundokanduang, perubahan peran 
perempuan Minangkabau serta pemakain tenunan songket dalam perubahan peranan perempuan Minangkabau di masyarakat.

\section{B. Tenunan Songket sebagai Pakaian Tradisional Bundokanduang}

Songket berasal dari dari kata songko, artinya saat pertama orang menggunakan benang hiasan kepala, ikat kepala disebut dengan songko. Di sisi lain ada pendapat lain yang menyatakan bahwa songket berasal dari kata tusuk dan cukik yang kemudian disingkat dengan Suk-Kit, selanjutnya berubah menjadi songket (Dinas Koperasi Pengusaha Kecil Menengah dan Penanaman Modal, Sumsel 2004).

Istilah menyongket berasal kata menyungkit menggunakan benang gimpal (emas dan perak), dengan menghias kain dengan berbagai motif selama proses penenunan. Menyungkit artinya mencongkel benang.Tenunan disebut dengan songket tersebut dalam kesejarahannya telah melahirkan beragam jenis motif, yang mengandung makna dan falsafah tertentu. Motif-motif yang lazimnya diangkat dari tumbuh-tumbuhan atau hewan (sebagian kecil) dikenal dengan variasi-variasi yang sarat dengan simbol-simbol yang mencerminkan nilai-nilai atas kepercayaan dan budaya Minangkabau.

Yandri (2003) menjelaskan kebudayaan menenun diperkirakan berkembang di Minangkabau semenjak periode 1656-1655, dimana pada saat itu tanaman kapas mulai dibudidayakan di Minangkabau. Selanjutnya kapas tersebut dibawa ke Padang sebagai pusat perdagangan dan diangkut ke pedalaman untuk diolah dan dikerjakan oleh penenun yang jumlahnya semakin hari semakin meningkat. 
Keterampilan menenun sebenarnya sudah dimiliki oleh masyarakat Minangkabau sebelum mereka mengenal pengolahan kapas menjadi benang. Raja Aditiawarman membangun kerajaan Minangbau dengan tektil Nusantara. Yandri (2003) menjelaskan keterampilan menenun gedongan (back strap loom) sudah dilakukan dengan baik untuk memenuhi pakaian kalangan bangsawan.

Setelah masuknya Islam ke Minangkabau, pedagang Arab memperkenalkan benang emas dan perak kepada masyarakat, sehingga masyarakat mulai menenun dengan benang emas dan perak. Keterampilan menenun selanjut berkembang dari rumah ke rumah dan akhirnya dikuasai oleh masyarakat. Dewasa ini daerah penghasil songket terkenal di Minangkabau adalah Pandai Sikek, Silungkang, dan Kubang.

Perempuan yang memakai songket di Minangkabau masa silam adalah Bundokanduang untuk tangkuluak (tengkuluk), baju, salendang (selendang) dan kodek atau sarung. Tenun songket yang dipakai Bundokanduang untuk tangkuluak biasanya terbuat dari kain balapak dengan motif, diantaranya hias pucuak rabuang, saik ajik dan sebagainya. Tangkuluak biasanya dipakai di kepala perempuan dalam melambangkan rumah gadang. Bundokanduang adalah perempuan tua pemimpin rumah gadang, tempat berunding dan meminta nasehat bagi keluarga rumah gadang

Budiwirman (2003:94) menjelaskan jenis tengkuluak yang dipakai Bundokanduang terdiri dari : (1) tangkuluak baikek (tengkuluk diikat), (2) tangkuluak kompong, (3) tangkuluak basipek, dan (4) tangkuluak bugih.

Sedangkan baju yang dipakai Bundokanduang dikenal dengan baju kuruang (baju kurung). Baju kurung yang dipakai Bundokanduang biasanya ditenun secara khusus dengan benang emas. Sedangkan selendang yang dipakai terbuat dari songket 
balapak. Budiwirman (2003 :96) menjelaskan jenis salendang yang digunakan untuk salempang bagi Bundokanduang terdiri dari ; (1) salempang balapak, (2) salempang gabah, (3) salempang cukie kuniang, (4) salempang kurik putiah, (5) salempang tangan dan topi, (5) salempang bugih dan (6) salempang jao. Selanjutnya kodek yang dipakai Bundokanduang juga terbuat dari kain balapak. Kodek terbuat dari tenunan songket yang ditenun dari benang emas.

Dengan demikian tenunan songket dipakai oleh perempuan dalam upacara adat. Salah seorang perempuan yang memakai songket adalah Bundokanduang, untuk baju kurung, selendang dan sarung. Motif tenunan yang dipakai masa silam adalah. sirangkat, pucuak rabuang, saik kalamai, cukia baserak, saik ajik, biku-biku, siriah gadang, catua biteh, itiak pulang patang, da mudiak, balah kacang, salapah basauak, batang pinang, biku-biku, balah katupek, palo bapatah,dan tampuak manggih

\section{Perubahan Peranan Perempuan Minangkabau}

Perkawinan dalam sistim kekerabatan matrilian di Minanangkabu ditandai oleh pihak mempelai laki-laki pindah ke rumah mempelai perempuan setelah menikah. Sebagian besar laki-laki Minangkabau dewasa ini berusaha membuatkan rumah untuk anak istrinya, sehingga ada kecenderungan untuk membentuk keluarga inti. Apabila terjadi perceraian, biasanya laki-laki meninggalkan rumah walau rumah tersebut dibuatnya dari hata penghasilan sendiri. Sedangkan perempuan Minangkabau kalau bercerai dengan suaminya, mereka akan berusaha membesarkan anak-anaknya dengan mengambil alih posisi sebagai kepala rumah tangga. 
Selanjutnya perubahan sosial yang terjadi dalam masyarakat Minangkabau ditunjukkan oleh peranan penting perempuan dalam perekonomian keluarga. Syahridal Dahlan (2004) menjelaskan Di Kabupaten Agam, Kota Bukittinggi, Kabupaten Lima Puluh Kota dan Kota Payakumbuh tampak bahwa industri kecil, makanan dan rumah tangga berkembang dengan pesat yang umumnya dikepalai oleh perempuan. Perempuan sudah dapat mengambil kredit untuk usahanya baik dari perindustrian maupun lembaga-lembaga lainnya. Bahkan ada yang sudah sangat lancar usaha ekspor kerajinan seperti bordir dan pakaian jadi ke negara tetangga, seperti Malaysia, Singapura, Brunai dan sebagainya.

Kesempatan perempuan Minangkabau untuk bekerja di luar rumah tidak hanya didasarkan oleh kondisi ekonomi tetapi didorong oleh kebutuhan yang berasal dari dalam diri perempuan itu sendiri untuk mengaktualisasikan dirinya. Miller (1984) telah melakukan penelitian dan menyimpulalkan $87 \%$ dari perempuan yang diteliti mencapai prestasi dalam pekerjaan, sedangkan $58 \%$ menyebutkan mereka lebih memilih pekerjaan di luar rumah. Penelitian lain ditemukan sebagian besar perempuan diusia dewasa bekerja di luar rumah berpandangan bahwa pekerjaan mempuanyai arti penting dalam hidupnya.

Perkembangan karir perempuan yang bekerja di luar rumah berlainan satu dengan lainnya. Tuntutan keluarga merupakan salah satu faktor yang mempengaruhi namun demikian perempuan tetap berpartisipasi dalam angkatan kerja. Frieden (1986) menjelaskan lima ciri pekerja wanita, yaitu (1) tidak ada pengalaman, (2) hanya bekerja sampai menikah/melahirkan anak, (3) bekerja sambil membangun keluarga, (4) bekerja kembali setelah anak besar dan (5) tidak menikah dan meningkatkan karir. 
Kesempatan berperan di luar rumah, menyebabkan terjadinya perubahan aktifitas perempuan Minangkabau. Kegiatan di sektor domestik yang biasanya dilakukan secara utuh sudah mulai meluas ke sektor publik. Iklim sosial masyarakat Minangkabau lebih menganggap dunia kerja adalah dunia laki-laki. Hal ini terungkap dari harapan terhadap perempuan yang bekerja di luar rumah, agar dapat bekerja dan tidak melupakan kodrat sebagai ibut rumah tangga.

Berkembangkannya aktifitas perempuan Minangkabau di sektor publik menuntut mereka untuk memanfaat waktu dengan efektif dan efesien. Begitu juga dalam pemilihan pakaian dilakukan berdasarkan kepantasan serta efektif dan efesien untuk dapat menuntup aurat. Masa silam perempuan apabila mengunjunggi mertua atau menghadiri upacara adat memakai tenun songket. Dewasa ini sebagain perempuan Minangkabau memilih pakaian dengan pertimbangan efektif dan efesien serta sesuai dengan tuntutan pekerjaan yang sedang dijalaninya.

Mode dan bahan pakaian yang dipilih dengan pertimbangan terjangkau, mengikuti zaman dan dapat menutup aurat. Tidak jarang perempuan Minangkabau dewasa ini mengikuti mode pakaian yang sedang trend di pasaran, walaupun kadangkadang mereka memadukan dengan jilbab sebagai ciri khas perempuan muslim.

\section{Pemakaian Songket dalam Perubahan Peran Perempuan di Minangkabau}

Tenunan songket dewasa ini di lingkungan masyarakat Minangkabau tidak hanya dipakai untuk melaksanakan upacara adat, tetapi keperluan lain, seperti: acara wisuda, menyambut tamu, interior dan sovenir dalam bentuk tas, dompet, sandal dan sebagainya. 
Perubahan penggunaan tenunan songket menurut Ibrahim (1986:3) disebabkan oleh pemakaian dan pembuatan pakaian adat di Minangkabau diajarkan secara lisan dan berlangsung secara turun temurun. Pengetahuan tersebut tidak diperoleh secara tertulis sehingga tradisi pakaian adat serta perhiasan dan kelengkapannya mudah berubah.

Selanjutnya Budiwirman (2003:113) menjelaskan pesatnya pertumbuhan ekonomi meningkatkan daya beli masyarakat untuk mengkonsumsi songket. Masa silam songket hanya dapat dibeli orang berduit karena harganya mahal dan dipakai untuk kepentingan upacara adat, tetapi songket dewasa ini telah dapat diberli oleh masyarakat dari berbagai lapisan dalam bentuk pakaian dan sovenir.Apabila ditinjau dari pengrajin songket, perubahan produk disebabkan oleh kepentingan komersial, selanjutnya melahirkan kreasi-kreasi dalam bentuk sovenir, seperti tas, dompet, sandal, dan hiasan dinding.

Songket tradisional Minangkabau terdiri dari motif : sirangkat, pucuak rabuang, saik kalamai, cukia baserak, saik ajik, biku-biku, siriah gadang, catua biteh, itiak pulang patang, da mudiak, balah kacang, salapah basauak, batang pinang, biku-biku, balahkatupek, palo bapatah dan ,tampuak manggih. Setiap motif bersandarkan kepada nilai-nilai : Alam takambang jadi guru, (alam terkembang jadi guru) adat basandi syarak, syarak basandi kitabullah (Adat bersendikan syarak dan syarak bersendirkan kitabullah). Akibat kontak budaya dan kebutuhan pasar,dewasa ini berbagai motif tenunan songket, sebagian sudah tidak dikenal lagi jenis motifnya (Budiwirman (2003:116). 
Pergeser fungsi tenunan songket sebagai simbol dalam upacara adat bagi perempuan Minangkabau mempunyai makna tersendiri. Pemakaian songket sudah dipakai oleh masyarakat luas dari berbagai lapisan. Kegiatan pengrajin yang awalnya untuk mengisi waktu senggang di samping bekerja sebagai petani, sudah beralih untuk memenuhi permintaan pasar. Bagi pengrajin kegiatan menenut juga mengalami perubahan untuk tujuan-tujuan komersial. Untuk kepentingan pariwisata, pemerintah daerah memasarkan tenunan songket Minangkabau ke seluruh penjuru dalam upaya peningkatan Pendapatan Asli Daerah (PAD). Motif dan warna songket dari hari ke hari mulai berubah sesuai dengan kebutuhan pasar.

Tenunan songket dari berbagai model dan bentuk dipasarkan di berbagai toko sovenir baik yang berada di Minangkabau maupun luar daerah. Para turis mancanegara maupun domestik tidak jarang membeli tenunan songket Minangkabau untuk oleh-oleh dan dipakai sendiri. Masyarakat memandang pakaian tenunan songket adalah pakaian berkelas dan dipakai dalam acara yang sangat bergensi.

Di samping itu, tenunan songket dipakai juga untuk menggambarkan identitas suku Minangkabau. Berbagai hotel menjadikan songket Minangkabau sebagai bahan interior, begitu juga perusahaan rekaman lagu-lagu Minangkabau dalam memasarkan produk kaset/CD/VCD, menggunakan tenunan songket baik untuk keperluan rekaman maupun hiasan sampul.Selanjutnya tenunan songket tidak jarang ditemukan dipakai perempuan Minangkabau dalam penyambutan tamu pemerintah, dan keperluan pelayan hotel serta pertunjukan tari tradisional untuk menunjukan identitas etnik Minangkabau. 
Perubahan pengunaan pakaian adat oleh perempuan Minangkabau, salah satu hal tergantung oleh proses sosialisasi dari satu generasi ke generasi berikutnya. Sebagian pakaian yang telah diwariskan tidak dapat dipakai bukan karena disebabkan oleh usia tetapi karena dimensi pakaian berbeda dengan pewaris pakaian tersebut . Konsekuensi dari hal itu, pakaian tersebut hanya berfungsi simbolik dan kurang fungsional bagi perempuan Minangkabau dalam masyarakat. Berbagai keterampilan berpakaian, diantaranya membuat tangkuluak tanduak sudah tidak dimiliki oleh semua perempuan Minangkabau. Demi kepraktisan tidak jarang tengkuluak tanduak dirancang khusus dan dibuat siap pakai oleh pedagang, dalam upaya mengatasi kelemahan tersebut.

Budiwirman (2003:133) menjelaskan perbedaan rentang waktu menyebabkan secara tidak disadari pola pakaian lebih banyak ditentukan oleh si pemesan dari pada oleh pembuat (produsen). Secara tidak langsung banyak ditemukan pola-pola kompromi antara produsen dan konsumen.

Kondisi tersebut disebabkan oleh peran sosial yang harus dilakukan perempuan Minangkabau dewasa ini semakin komplek, sehingga mereka memerlukan kepraktisan dalam berpakaian. Dewasa ini perempuan Minangkabau lebih mempertimbangkan kenyamanan dan kepraktisan sesuai dengan tuntutan peran sosial yang harus mereka lakukan dalam situasi tertentu. Tenunan songket tidak hanya dipakai untuk upacara adat tetapi sudah meluas ke kegiatan lain, seprti upacara pelantikan, wisuda dan untuk keperluan sovenir. 


\section{E. Penuntup}

Masa silam tenunan songket dipakai oleh perempuan Minangkabau dalam upacara adat. Salah seorang perempuan Minangkabau yang memakai songket adalah Bundokanduang, untuk baju kurung, selendang dan sarung. Motif tenunan yang dipakai masa silam adalah: sirangkat, pucuak rabuang, saik kalamai, cukia baserak, saik ajik, biku-biku, siriah gadang, catua biteh, itiak pulang patang, da mudiak, balah kacang, salapah basauak, batang pinang, biku-biku, balah katupek, palo bapatah,dan tampuak manggih.

Berkembangkannya aktifitas perempuan Minangkabau di sektor publik menuntut mereka untuk memanfaat waktu dengan efektif dan efesien. Begitu juga dalam pemilihan pakaian dilakukan berdasarkan kepantasan serta efektif dan efesien untuk dapat menuntup aurat. Masa silam perempuan apabila mengunjunggi mertua atau menghadiri upacara adat memakai tenun songket. Dewasa ini sebagain perempuan Minangkabau memilih pakaian dengan pertimbangan efektif dan efesien serta sesuai dengan tuntutan pekerjaan yang sedang dijalaninya.

Perubahan peran perempuan Minangkabau dalam masyarakat, menyebabkan pemilihan mode dan bahan pakaian yang dipilih dengan pertimbangan terjangkau, mengikuti zaman dan dapat menutup aurat. Tidak jarang perempuan Minangkabau dewasa ini mengikuti mode pakaian yang sedang trend di pasaran, walaupun kadangkadang mereka memadukan dengan jilbab sebagai ciri khas perempuan muslim. Penggunaan songket bagi masyarakat Minangkabau sudah mulai meluas untuk kepentingan hotel dalam interior, begitu juga perusahaan rekaman lagu-lagu Minangkabau dalam memasarkan produk kaset/CD/VCD, menggunakan tenunan 
songket baik untuk keperluan rekaman maupun hiasan sampul. Selanjutnya tenunan songket tidak jarang ditemukan dipakai perempuan Minangkabau dalam penyambutan tamu pemerintah, dan keperluan pelayan hotel serta pertunjukan tari tradisional untuk menunjukan identitas etnik Minangkabau. Motif yang diproduksi oleh pengrajin dewasa ini sebagian sudah tidak dikenal lagi, karena perkembang ilmu pengetahuan, kontak budaya serta kebutuhan pasar. 


\section{Daftar Kepustakaan}

Budiman, Arif (1992) : Pembagian Kerja Secara Seksual. Yogyakarta : Kanisius

Budiwirman (2003) : Kain Tenun Songket Minangkabau (Kajian Fungsional Songket dalam Perubahan Sosial-Budaya Masyarakat Minangkabau). Padang : Program Pascasarjana Universitas Negeri Padang.

Dinas Koperasi Pengusaha Kecil Menengah dan Penanaman Modal (2004) : Tenunan Tradisional Songket Sumatera Selatan. Palembang : Pemerintah Propinsi Sumatera selatan.

Firman (1998) : Peran Wanita dalam Keluarga. Padang: FIP IKIP Padang.

Frieden, Betty (1986) : The Second Stage. New York : Sumit Books

Ibrahim, Anwar (1986:3) : Pakaian Adat Tradisional Daerah Sumatera Barat. Padang : Departemen Pendidikan dan Kebudayaan , Direktorat jenderal Kebudayaan, Direktorat Sejarah dan Nilai Tradisional, Proyek Inventarisasi Dokumen Daerah.

Yandri (2003) : Suatu Tinjauan Dunia Seni dan Kerajinan Sumbar, Keberadaan dan Perubahan Kerajinan Songket. Padang Panjang: STSI. 


\section{PEMAKAIAN SONGKET DALAM PERUBAHAN PERANAN PEREMPUAN MINANGKABAU DI MASYARAKAT}

\section{Oleh}

Dr. Firman.MS

Disampaikan dalam Seminar Songket Serumpun Melaka 2003, yang Dilaksanakan oleh Kementrian Kebudayaan Kesenian dan Warisan Malaysia Bekerjasama dengan Majlis Tindakan Pelancongan Negeri Melaka, Institut Seni Malaysia Melaka dan Bagian Promosi Pelancongan Negeri Melaka.

\section{FAKULTAS ILMU PENDIDIKAN} UNIVERSITAS NEGERI PADANG 2003 
